UDC 347.1

DOI https://doi.org/10.37687/2413-6433.2020-2.5

\author{
Kmak M.K., \\ PhD of Humanities in the field of Political Science, \\ Department of Sustainable Development Research \\ Institute of Law, Administration, Economics \\ of the Pedagogical University of Cracow \\ ORCID: 0000-0002-2285-5793
}

\title{
POLICE IN POLAND: ORGANISATION AND TASKS (LEGAL ASPECT)
}

\section{ПОЛІЦІЯ В ПОЛЬЩІ: ОРГАНІЗАЦІЯ ТА ЗАВДАННЯ (ПРАВОВИЙ АСПЕКТ)}

Ensuring public safety and order is a task of many bodies which in the doctrine are referred to as the Administrative Police. The article presents an outline of the history of the Police in Poland. The author explores the historical and legal aspects of the formation and development of the police in Poland: the need to maintain law and order was an important aspect of the security of the Polish state as early as the 10th century. The formation of the Police was a long-term process, which in Poland began in the early Piasts times. Between the 10th and 12th centuries, the judicial, administrative and police functions were not separated, therefore many officials performed them simultaneously. A significant development of this law enforcement body took place in the 17th and 18th centuries, when the aim was to strengthen the power of the ruler and to discipline the subjects completely. In the 19th century in the Kingdom of Poland demonstrates that the system of police units was expanded. Great emphasis was placed on observations of Polish independence circles. An important role at that time was played by the gendarmerie, which was used for police tasks. Between 1919 and 1939 several important changes were made in the State Police system. In 1920, the Police was militarised due to the ongoing war with the Soviets. The establishment of the State Police, called the Citizen's Militia, by the decree of the Polish Committee for National Liberation in 1944 was an important element in the history of the Police. In 1954 as a result of the decree on the main state administration bodies in the field of internal affairs and public security and the Militia became separated from public security bodies. In 1989, as a result of economic and political changes took place in Poland and other European countries the security forces underwent a transformation. The adoption of the Police Act in 1990 was an evolutionary moment for police units. The functioning of the Police in the 21 st century has been based on it. The article examines in detail the current functions of the Police in Poland and makes suggestions for improving the functioning of these state bodies and the legal regulation of their activities. Regulations are understood as rules and regulations which aim to regulate activities, tasks within an institution, obliging employees and members to obey them. With regard to institutions like the Police, regulations are normative acts, issued by authorities. The main tasks performed in everyday life have been indicated and the basic legal forms of activity of the Polish Police have been specified. The contents of this article do not cover the entire area of research and constitute only a selected aspect of a wider scientific research.

Key words: police, administration, structure, function, security.

Забезпечення громадської безпеки й порядку є завданням багатьох органів, які в доктрині називаються адміністративною поліцією. Стаття представляє історію поліції в Польщі. Авторка досліджує історико-правові аспекти формування й розвитку поліції в Польщі, адже необхідність підтримання правопорядку була важливим аспектом безпеки польської держави ще на початку Х століття. Формування поліції було тривалим процесом, який у Польщі розпочався за правління династії П'ястів. У період між X і XII століттями судові, адміністративні та поліцейські функції не були розділені, тому багато чиновників виконували їх одночасно. Значний розвиток система цих правоохоронних органів отримала в XVII-XVIII століттях, коли визріла мета зміцнення влади правителя з прагненням повністю дисциплінувати підданих. У ХІХ столітті в Королівстві Польському розпочинається процес розширення системи поліцейських органів. У цей час головний акцент був зроблений на спостереженнях за діяльністю польського руху за незалежність. Важливу роль тоді відігравала жандармерія, яка використовувалася для виконання поліцейських завдань. У період між 1919 та 1939 роками вже в межах незалежної Польської держави до системи державної поліції було внесено декілька важливих змін. У 1920 році поліцію було мілітаризовано через триваючу війну з Радянською Росією. Ще одним важливим етапом у розвитку поліції було створення Державної поліції, яку називали Громадянською міліцією згідно з указом Польського комітету національного визволення 1944 року. У 1954 році внаслідок видання Указу про головні органи державного управління у сфері внутрішніх справ та громадської безпеки міліція відокремилася від органів державної безпеки та стала на службу тодішнього режиму. У 1989 році в результаті економічних і політичних змін у Польщі та інших європейських країнах сили безпеки зазнали змін. Прийняття Закону про міліцію в 1990 році стало еволюційним моментом для поліцейських підрозділів. 
На цьому базується функціонування поліції у XXI столітті. У статті детально розглядаються поточні функції поліції в Польщі та вносяться пропозиції щодо вдосконалення функціонування цих державних органів, правового регулювання їх діяльності. Правове регулювання розглядається як реалізація нормативних актів, спрямованих на регулювання діяльності, завдань в установі, що зобов'язують підрозділи поліції та їхніх працівників. Названо основні завдання, які виконуються в повсякденному житті, та визначено основні правові форми діяльності польської поліції. Зміст статті не охоплює всю сферу досліджень і становить лише вибраний аспект більш широкого наукового дослідження.

Ключові слова: поліиія, адміністрація, структура, функиії, безпека.

Introduction. The position of the Police in the system of public administration authorities has been changing over the years. The Police, as a unit, has been present in the history of Poland since the Piasts dynasty, i. e. since the 10th century. The process of formation of this body has been long and it has taken various shapes. Regardless of the name, structure and subordination, it has always been an armed formation, serving the state, whose aim has been to protect security and public order. The political and economic changes, initiated in 1990 also influenced the legal transformations in the structure and scope of the Police. A new law was passed, which to some extent referred to the interwar period solutions. Although the act in its original version was imperfect, containing many ambiguities and gaps, it became a foundation for a new definition of the legal position of the Police as a formation serving not only the state but also the society. The main aim of the article is to characterise the Police as an organ in the structure of public administration and to present its organisation and functions. Since 1 January 1999, the police authorities have been a part of structures of a combined government administration - with the province governor as its superior at the province level and the district governor at the district level. In this way the position of a province governor was strengthened in relation to these bodies. This fact makes a significant change in the legal and organisational structure of the Police. Currently, the Police is a strongly hierarchical unit, where interactions between the posts are made through official orders.

Police: historical outline

The need to maintain law and order was an important aspect of the security of the Polish state as early as the 10th century. The formation of the Police was a long-term process, which in Poland began in the early Piast times. The word "policja" appears in the Polish history in the 16th century in Stanisław Orzechowski's work [8] - Policya Królestwa Polskiego, published in 1565 [5]. The term derives from the word "politeja", which in Greek means city management. The meaning of the term was very broad as it presented the general scope of state's functions. Between the 10th and 12th centuries, the judicial, administrative and police functions were not separated, therefore many officials performed them simultaneously [6]. In the prince's surroundings, there were such positions as "count of the palace", "mint master", "governor", "castellan" and "justycjariusz". The count of the palace not only administered and managed the royal court, but also performed tasks related to security. When a person from the prince's surroundings committed a crime, it was the count's responsibility to capture the criminal. In those times, the problem of counterfeiting of money also began to arise. A significant function at that time was performed by a mint master, who managed the national mint. Apart from collecting taxes, he was also engaged in the prosecution and punishment of people producing counterfeit coins. In the case of the governor, his tasks included administration of provinces, but also their internal security. The castellan performing judicial, administrative and police functions replaced the former castle commissary. Over time, the importance of this function diminished, and the primary task was to prosecute the killers, especially when the perpetrator was considered to be unknown. The justycjariusz was a local official, whose scope of activities would correspond to the tasks of today's police officer. He was more often called "executioner" because he was involved in stopping criminals. His role increased over time, he also dealt with investigative tasks, which made him the person who carried out the inquisition process. However, this office was abolished in the 15th century, as a result of the nobility's fear of his great interference in matters concerning their jurisdiction [6]. The body we call Police today performed its role between the 14th and 15th century and supported the authority of the state, while police law as the main norm reinforced the ruler's governance. A significant development of this law enforcement body took place in the 17 th and 18 th centuries, when the aim was to strengthen the power of the ruler and to discipline the subjects completely. The police law in force at that time represented the ruler's statements, which had legal force. This was supposed to ensure order in the state, and at the same time satisfy the subjects. The ruler's orders were to ensure stability. However, these standards covered only the obligations of the society, unfortunately not the rights [7]. From the 18th century onwards, committees of good order and civil-military order committees were established (1789). The unambiguous concept of police was defined in the French Criminal Code (1795) and Prussian Landrecht (1794). The changes of the content that took place over the centuries were factors influencing its final definition. Until that time, the activities of the Police had been included in the scope of administrative activities aimed at ensuring order and security. Analy- 
sis of the 19th century in the Kingdom of Poland demonstrates that the system of police units was expanded. Great emphasis was placed on observations of Polish independence circles. An important role at that time was played by the gendarmerie, which was used for police tasks. These tasks started to be defined more strictly [7, p. 47-83], new units were introduced. The establishment of the State Police under the act of 24 July 1919 was an important event in the history of the Polish Police. The newly created security organisation was an executive body, whose financing was handled by the state treasury. The structure was made up of regional police headquarters, district police headquarters and police stations in municipalities. Moreover, police guardhouses were created in emergency situations. An important role was played by the Chief of Police, who was the head of the entire State Police force. The earlier act of 5 December 1918 on the organisation of the People's Militia and the act of 9 January 1919 on the organisation of the Municipal Police were repealed by law [14]. The local authorities had considerable powers with regard to the Police, as the Police was obliged to provide assistance within the sphere of competence of the authorities and thus within the scope of police tasks. Between 1919 and 1939 several important changes were made in the State Police system. In 1920, the Police was militarised due to the ongoing war with the Soviets. At that time, it was not possible to leave the service as it was punishable by law. The Police were completely subordinated to the military. A few years later, in 1928, the existing state administration was decided to be transformed. The institution of the Police was also to be changed, by means of the new ordinance of 6 March 1928. The organisation of the unit was based on military models. It was subordinated to the administrative authorities in the area of public order and security, while in terms of training or personnel matters it was subordinated to the police superiors [9].

The year 1939 turned out to be difficult for the Police. Many officers died in the September attack. During the Nazi occupation, the Police was supervised by the chief of the Order Police and the criminal department was under the supervision of the chief of the Security Police [3, p. 1007].

The establishment of the State Police, called the Citizen's Militia, by the decree of the Polish Committee for National Liberation in 1944 was an important element in the history of the Police. It was a unit serving the protection of the public safety. The area of activity of the formation was vast, and thus these units could be used to fight the opponents of the ruling party [6].

Significant changes in the organisation of the Militia were introduced in 1954 as a result of the decree on the main state administration bodies in the field of internal affairs and public security. At that time the Militia became separated from public security bodies. Decree of 21 December 1955 concerning the organisation and operation of the Citizen's Militia was in force until 1983, when the new law on the office of the Minister of Internal Affairs and the scope of operation of subordinate bodies was introduced. According to this law, the Militia was an executive body of the Minister. The structure of the unit was also modified [7].

In 1989, economic and political changes took place in Poland and other European countries. The security forces underwent a transformation. The adoption of the Police Act in 1990 was an evolutionary moment for police units. The functioning of the Police in the 21st century has been based on it [6].

The concept, functions and characteristics of the Police

The Police, as an armed and formed unit, has two basic meanings in the Polish legal system formal and material. In the formal sense these are bodies so called by law, while in the material sense - authorities whose priority task is to take care of safety, order, peace and public order and to protect life, health and property. These activities should be carried out regardless of how the legislator has named a given body which has been appointed to protect the aforementioned values [18]. As the Police unit is similar in structure to the military system, it can be assumed that the uniforms and armaments as well as its official subordination are the distinguishing characteristic of the organisation. The above mentioned determinants, however, are not the most important. A police officer also performs tasks during which there is no need to carry a weapon or wear a uniform [2, p. 15]. Referring to the military patterns is aimed at raising awareness of the high rank of the law enforcement authority, as well as emphasising the strength and effectiveness of the Police. Armament in the form of firearms is a coercive measure, thanks to which the most dangerous attacks can be effectively suppressed. When it comes to the uniforms, they are an indicator of centralised management of the Police unit and its uniformity. The legislator, when creating the definition of this organisation, aimed at indicating the speed of its actions and the inhibition of potential threats [11, p. 166-167].

The Police exist for the purpose of protecting and maintaining public safety and order. These tasks are not only confined to the Police Act of 6 April 1990 [16], but they can also be found in other numerous legal acts. These activities are carried out for the benefit of the society that the Police should serve. The Police need to be apolitical in their actions. This increases the confidence of the society, the political neutrality of the unit reduces the risk of conflict. Regardless of which political party rules in the state, the Police carry out the tasks laid down by law, while taking care of proper respect for human dignity and the protection of human rights [11, p. 166-167]. 
The systemic principles resulting from the Constitution of the Republic of Poland [4] apply both to the activities of the Police and other state security bodies. The principle of a democratic state of law is the most important among them and according to it public administration bodies should function on the basis of and within the limits of the law in force. When taking action, officers of this unit are bound by the principle of legality concerning the sphere of the applied law. According to this rule, all actions undertaken by police officers should follow the formula: what is allowed is not prohibited [18, p. 182].

In accordance with the principle of unity, the supreme authority has a superior function over the others, which creates a hierarchical system. A special position is held by the Chief of Police, who is a competent authority for the protection of public safety and order and reports to the Minister of Interior Affairs [18, p. 182]. Referring to the principle of hierarchical subordination, all lower authorities are subordinate to higher authorities.

The principle of efficient operation obliges police officers to act quickly and effectively, basing on cost-effectiveness. This principle is related to the appropriate organisation of internal police branches, whose tasks are performed on the basis of previously selected forms of action. At the same time, it is connected with another rule - the principle of specialisation, which is expressed through the division of responsibilities between organisational units. Due to this division, branches dealing with relevant matters which require specialist training in a given field have been created. Officers are obliged to be available. This means they need to be ready to take action, sometimes even threatening life and one's own safety, in the name of social service [18, p. 183].

\section{Police tasks}

The basic tasks of the Police were defined in Article 1 section 2 of the Police Act of 6 April 1990 [16].

These include:

- "protection of life and health of people and property from unlawful attacks that violate these goods;

- protection of public safety, law and order, including ensuring tranquillity in public places and public transport and communication, on the road and on waters intended for use by the public;

- initiation and organisation of activities aimed at preventing crimes, misdemeanours and criminogenic phenomena and cooperating in this respect with state and local government bodies and social organisations;

- conduct of counter-terrorist activities within the meaning of the Act of 10 June 2016 on counterterrorist activities;

- detection of crimes and offences and prosecution of perpetrators;

- protection of facilities constituting the seats of members of the Council of Ministers, excluding facilities serving the Minister of National Defence and the Minister of Justice, indicated by the minister in charge of internal affairs;

- supervision of specialised armed protection forces to the extent specified in separate regulations;

- control of the observance of public order and administration regulations related to public activities or in force in public places;

- cooperation with the police forces of other countries and their international organisations, as well as with the bodies and institutions of the European Union on the basis of international agreements and separate regulations;

- collecting, processing and transferring criminal information;

- maintaining data sets containing information collected by authorised authorities on fingerprints, unidentified latents from crime scenes and the results of deoxyribonucleic acid (DNA) analysis" [16, art. 2].

When creating a set of tasks, the legislator listed them in a hierarchical order, starting with the most important ones. First of all, the most important objective of the functioning of the Police was indicated, which is to protect people and their property. Activities aimed at preventing public order violations were also specified. Moreover, attention was drawn to the aspect of making the society aware of the acts committed, adopting the principle that it is better to prevent than to impose a penalty straight away. Another and at the same time one of the most important tasks is the location of crimes and offences, combined with the search for their perpetrators, which ends with the application of appropriate repressive measures against them. Within the framework of these activities, the Police make use of the implementing measures indicated in the administrative procedure code, the code of procedure for misdemeanour cases and the penal code. The tasks also include international cooperation with police forces, which is based on international agreements [1].

In connection with the tasks performed, the Police carry out activities of investigative, operational and exploratory, administrative and orderly nature, the aim of which is to identify, suppress and locate crimes and offences, prosecute persons hiding from justice, find those who have been granted the status of missing persons [16, art. 14]. In carrying out these activities, police officers have the tools to make them more effective.

Such actions are understood as the right to:

- "check the identity of persons;

- arrest persons, in accordance with the principles set out in the penal procedure code, and those who pose a real threat to life and health;

- detain persons on temporary release and who,

for some reasons, have not returned to prison;

- take mucosal swabs and fingerprints from indicated persons;

- search people as well as rooms;

- monitor and record images from rooms where detainees are present, as well as perform the same 
activities in public places, with the additional possibility of sound recording" [16, art 15(1)];

- "demand the necessary assistance from state institutions, government and local government administration bodies as well as entrepreneurs performing public utility tasks; the mentioned institutions, bodies and entrepreneurs are obliged, within their field of activity, to provide assistance, in the scope of binding legal regulations;

- seek necessary assistance from other entrepreneurs and social organisations, as well as, in case of emergency seek aid from any person, within the framework of the applicable legislation" [16, art. 15(1) 6-7].

While carrying out their duties, police officers face various, often unpredictable difficulties, therefore they also have the possibility to use direct coercive measures against persons. This coercion is manifested by the use of auxiliary means: "physical force, handcuffs, straitjacket, body belt, neutralising net, safety helmet, truncheon, waterbased incapacitating agents, dog or horse, nonpenetrative bullet, chemical incapacitating agents, objects designed to incapacitate persons with electricity, isolation room, spike strip and other means to stop and immobilise motor vehicles, service vehicles, means to overcome building closures and other obstacles (including explosives), pyrotechnics with stunning or dazzling properties" [15, art. 12].

\section{Legal forms of police activity}

In Poland, the establishment of police service takes place by nomination, and the application for service is voluntary. The nomination takes the form of an administrative act, unilateral, on the basis of which a given candidate is commissioned to perform tasks on a specific position [3, p. 1007]

The catalogue of legal forms of activity is very extensive. In the case of the Police, a body which has a peculiar character in the system of public administration, it is closely related to the scope of functions performed by it [10].

These include:

- "functions related to the implementation of tasks in the sphere of public administration;

- criminal prosecution functions;

- justice system functions;

- functions relating to administrative proceedings;

- functions related to the performance of tasks delegated by other state and public administration bodies" [10, p. 12].

Among the legal forms of police activity, one of the most important and basic ones is issuing individual administrative acts. An administrative act should be understood as "an individual, unilateral legal act of a public administration body, which may be issued in cases provided in the act or in another general legal act in the field of administrative law" $[12 ; 13]$. In many cases the acts take the form of an administrative decision. Concerning the activities of the Police, an administrative decision occurs when this authority, on the basis of administrative proceedings or special provisions, announces decisions which concern particular matters, e. g. road transport [17]. Each decision is issued on the basis of an act which regulates a given scope, through administrative proceedings. The whole requires both instance and court control.

Issuing internal administrative acts is an example of another form of activity. Its regulation is contained in the Order № 17 of the Chief of Police of 14 May 2014 on methods and forms of performing tasks in the Police with regard to legislation, legal assistance and legal information [19].

Orders, regulations, decisions, guidelines are considered as internal acts. In the case of an order, it is understood to be a normative act, which is issued on the basis of an act, by:

- police authorities;

- police school chiefs;

- Director of the Central Police Forensic Laboratory;

- Commander - Rector of the Police Academy in Szczytno [10, p. 21].

Examples of internal law acts that constitute orders are:

- Order № 51 of the Chief Commander of the Police of 10 August 2018 amending the order on methods and forms of reporting in the Police (Journal of Laws 2018.85) [23];

- Order № 17 of the Chief of Police, 14 May 2014 on methods and forms of performing tasks in the Police with regard to legislation, legal assistance and legal information (Journal of Laws 14 May 2014) [19];

- Order № 26 of the Chief of Police of 19 February 2018 on methods and forms of rejection of non-archival documentation in the Police (Journal of Laws 2018.34) [20];

- Order № 30 of the Chief of Police of 22 September 2017 on performing service on the roads (Journal of Laws 2017.64) [22].

Regulations are understood as rules and regulations which aim to regulate activities, tasks within an institution, obliging employees and members to obey them. With regard to institutions like the Police, regulations are normative acts, issued by authorities such as: commanders of specialist police stations, police bodies, police school commanders, Director of the Police Central Forensic Laboratory, Commander of the Police Academy in Szczytno [10, p. 21]. These regulations are issued in the form of acts which define the structure of a given organisational unit (tasks of units forming these organisations, mode of introduction of job description cards) [10, p. 22].

Decisions are acts of management and they are issued by managers of given organisational units of the Police. The purpose of the issued decisions is to define specific tasks which will apply to subordinate units and organisational units of the bodies. The 
guidelines constitute the last internal act relating to police units. They are issued by the Chief of Police. These are supervision acts that are to explain the content of normative acts and show the way to their best possible application [21, art. 1(50)].

The legal forms of police activity include material and technical activities. They consist of the performance of activities having specific legal effects. They shape legal relations by facts, and not by standards of conduct. An example of such an activity may be a situation in which police officers carry out speed measurements and a given driver fails to comply with them, in which case they may punish him/ her with a fine in the form of a traffic ticket. Material and technical activities are defined by legal regulations, which results in the obligation to adapt to them and to obey them [10, p. 21].

The socio-organisational activity is another legal form of police operation. There is a problem in the analysis of this issue when it comes to creating a catalogue, which would indicate the forms and means of action in a comprehensive manner. This activity is characterised primarily by the lack of power and interference in the sphere of freedom and human rights, as well as regarding citizens. Therefore, the task of the Police is to select the most appropriate means of action and forms that would lead to the achievement of a specific goal. The standard of competence is the basis for the application of this activity. In terms of everyday life, the provision of information by means of the mass media, done by the Police spokespersons constitutes an example of social and organisational activity of the Police. These activities have a positive impact on the development of prevention in the society, which contributes to a greater awareness and a sense of security [10, p. 28-29].

With regard to the civil-law agreement, another example of the legal form of police activity, it can be found only in the internal sphere, which is related to the performance of tasks that shape property relations and the management of property belonging to the Police [10, p. 29].

The administrative agreement is another legal form of police activity, which is applied in the implementation of tasks directly related to guaranteeing the safety of people and ensuring public order. Despite the differences between the entities in legal, economic and organisational matters, the agreements may be made by them. The Police may conclude such an agreement with government administration bodies, local government, foundations, etc. It constitutes a bilateral or multilateral activity on the basis of legal regulations. The matters covered in the agreement and the rules of operation constitute the content of this agreement. The subject matter of the agreement relates to the matters that fall within the competence of the entities that conclude it [10, p. 29-30].

Conclusions. During the analysis of the process of creation and development of the Police formation in Poland over the centuries, it becomes visible that the legal acts, coming both from the state and from the formation itself, had a great influence on its course. Due to the hierarchy of the structure of the unit, it is necessary to create a sequence of clearly indicated tasks and responsibilities to ensure its proper functioning. Only the Police that is operating efficiently can fully perform the tasks entrusted to it, which constitute its mission - the protection of public safety and order. The candidates who are properly selected for service in the Police constitute an important element of an efficient Police. Predisposition and identification with the profession guarantees reliable performance of duties. The security of each unit and of the whole country depends on the efficient functioning of this body.

\section{References:}

1. Bonisławski M. Zadania Policji w zakresie bezpieczeństwa i porządku publicznego. Zeszyty Naukowe WSEI. Seria "Administracja". 2015. Vol. 5. S. 135-136.

2. Hanausek T. Ustawa o Policji. Komentarz. Cracow : Wydawnictwo Zakamycze, 1996. $166 \mathrm{~s}$.

3. Hołyst B. Policja na świecie. Warszawa : LexisNexis, 2013.1328 s.

4. Konstytucja Rzeczypospolitej Polskiej z dnia 2 kwietnia 1997 r. uchwalona przez Zgromadzenie Narodowe w dniu 2 kwietnia 1997 r., przyjęta przez Naród w referendum konstytucyjnym w dniu 25 maja 1997 r., podpisana przez Prezydenta Rzeczypospolitej Polskiej w dniu 16 lipca 1997 r. URL: http://isap.sejm.gov.pl/isap.nsf/DocDetails. xsp?id=WDU19970780483 (access: 11.08.2020).

5. Malec J. Zakres i znaczenie terminu ,policja” w literaturze politycznej schyłku Rzeczypospolitej szlacheckiej. Studia Iuridica Lublinensia. 2016. Vol. XXV(3). S. 617-628.

6. Misiuk A. Historia Policji w Polsce od X wieku do współczesności. Warsaw : Wydawnictwa Akademickie i Profesjonalne Spółka z o.o., 2008. 228 s.

7. Pieprzny S. Policja-organizacja i funkcjonowanie. Warszawa : Wolters Kluwer, 2007. $160 \mathrm{~s}$.

8. Policya Królestwa Polskiego na kształt aristotelesowych polityk wypisana i na świat dla dobra pospolitego trzema księgami wydana przez Stanisława Orżechowskiego. URL: https://www.wbc.poznan.pl/dlibra/publication/924/ edition/1365/content (access: 10.08.2020).

9. Rozporządzenie Prezydenta Rzeczypospolitej z dnia 6 marca 1928 r. o Policji Państwowej. URL: http://isap.sejm.gov.pl/isap.nsf/DocDetails.xsp?id=WDU19280280257 (access: 10.08.2020). 
10. Róg M., Sęk A. Materialno-administracyjne aspekty pracy Policji. Pułtusk ; Warszawa : Akademia Humanistyczna im. A. Gieysztora-Wydział Administracji, 2015. 173 s.

11. Rudnicka M. Ogólna charakterystyka Policji, jako formacji uzbrojonej i umundurowanej oraz jej wielowymiarowość. De Securitate et Defensione. O Bezpieczeństwie i Obronności. 2016. Vol. 2(2). S. 164-176.

12. Akt administracyjny. Słownik Języka Polskiego - Encyklopedia PWN. URL: https:/encyklopedia.pwn.pl/haslo/ aktadministracyjny;3867022.html (access: 06.08.2020).

13. Szewczyk E., Szewczyk M. Generalny akt administracyjny. Warszawa : Wolters Kluwer, 2014. $251 \mathrm{s.}$

14. Ustawa z dnia 24 lipca 1919 r. o policji państwowej. URL: http://isap.sejm.gov.pl/isap.nsf/DocDetails. xsp?id=WDU19190610363 (access: 10.08.2020).

15. Ustawa z dnia 24 maja 2013 r. o środkach przymusu bezpośredniego i broni palnej. URL: http://isap.sejm.gov.pl/ isap.nsf/DocDetails.xsp?id=WDU20130000628 (access: 11.08.2020).

16. Ustawa $\mathrm{z}$ dnia 6 kwietnia 1990 r. o Policji. URL: https://isap.sejm.gov.pl/isap.nsf/DocDetails. xsp?id=WDU19900300179 (access: 09.08.2020).

17. Obwieszczenie Marszałka Sejmu Rzeczypospolitej Polskiej z dnia 14 września 2012 r. w sprawie ogłoszenia jednolitego tekstu ustawy o transporcie drogowym. URL: http://isap.sejm.gov.pl/isap.nsf/DocDetails. xsp?id=WDU20120001265 (access: 10.08.2020).

18. Warmiński A. Administracja bezpieczeństwa i porządku publicznego w Polsce. Warszawa : Dom Wydawniczy Elipsa, 2013. $470 \mathrm{~s}$.

19. Zarządzenie № 17 Komendanta Głównego Policji z dnia 14 maja 2014 r. w sprawie metod i form wykonywania w Policji zadań w zakresie legislacji, pomocy prawnej i informacji prawnej. URL: http://bip.kgp.policja.gov.pl/kgp/ wolnytekst/52,Zarzadzenie-nr-17.html (access: 11.08.2020).

20. Zarządzenie № 26 Komendanta Głównego Policji z dnia 19 lutego 2018 r. w sprawie metod i form brakowania dokumentacji niearchiwalnej w Policji. URL: https://isp.policja.pl/isp/aktualnosci/prawo/12532,Zarzadzenie-nr-26Komendanta-Glownego-Policji-z-dnia-19-lutego-2018-r.html (access: 11.08.2020).

21. Zarządzenie № 30 Komendanta Głównego Policji z dnia 16 grudnia 2013 r. w sprawie funkcjonowania organizacji hierarchicznej w Policji. URL: http://edziennik.policja.gov.pl/api/DU_KGP/2013/99/journal/2363 (access: 11.08.2020).

22. Zarządzenie № 30 Komendanta Głównego Policji z dnia $2 \overline{2}$ września 2017 r. w sprawie pełnienia służby na drogach. URL: https://isp.policja.pl/isp/aktualnosci/prawo/11764,Zarzadzenie-nr-30-Komendanta-Glownego-Policji-zdnia-22-wrzesnia-2017-r.html (access: 11.08.2020).

23. Zarządzenie № 51 Komendanta Głównego Policji z dnia 10 sierpnia 2018 r. zmieniające zarządzenie w sprawie metod i form prowadzenia sprawozdawczości w Policji. URL: https://isp.policja.pl/isp/aktualnosci/ prawo/13529,Zarzadzenie-nr-51-Komendanta-Glownego-Policji-z-dnia-10-sierpnia-2018-r.html (access: 11.08.2020). 